\title{
Obituary
}

\section{RICHARD BROKE FREEMAN: 1 April 1915-1 September 1986}

After graduating in zoology at Magdalen College, Oxford in 1938, Richard Freeman spent the war of 1939-1945 as a pest control officer for the Ministry of Agriculture and Fisheries. He also reached the rank of major in the Anti-Aircraft Home Guard, commanding more than a thousand men, mostly from the Cowley motor works at Oxford, about whom he later spoke with the same affection as he did about his students. He was awarded the M.B.E. for his Home Guard service. In 1947, he joined University College London as a lecturer in zoology, and he was Reader in Taxonomy from 1952 until his retirement in 1982. As Emeritus Reader, he still visited the College regularly, continuing his bibliographical and historical research and providing stimulating conversation for his friends in the common room.

Freeman's taxonomic research was on insects, an interest which arose when he was a young field naturalist, but he had an extensive knowledge of all branches of natural history which he willingly shared with others. An enthusiastic book collector, Freeman became a brilliant bibliographer. His Natural History Books 1495-1900: A Handlist (1980) contains descriptions of approximately 4200 books on the fauna and flora of the British Isles (including the Channel Islands and Heligoland) and general natural history books written by their inhabitants, the fruit of many years of collecting, visiting libraries and corresponding with dealers and with other scholars.

His principal historical interest was in Charles Darwin-his life, work and family. The Works of Charles Darwin: An Annotated Bibliographical Handlist (1965; 2nd edn, 1977) is an indispensable reference book for Darwin scholars, in which he established new standards for scientific bibliography. The 1805 items include all editions, reprints and translation of Darwin's publications, and it is clear that he studied them closely. He showed, for example, that Darwin often corresponded with translators of his works, so some translations include alterations made by Darwin himself which are not in the English editions.

In his remarkable Charles Darwin: $A$ Companion (1978) Freeman included, in an alphabetical sequence, descriptive and critical comments on every person mentioned in Darwin's works and published correspondence, as well as many place names and other relevant topics. Two examples must suffice from about 150 entries under the letter ' $B$ '. From the account of $\mathrm{H}$. W. Bates, we learn that the review of Bates' book on the insects of the Amazon valley was one of only two reviews that Darwin ever wrote; and the entry for the Beagle not only gives complete itineraries of all three of her surveying voyages but shows that she was the third ship of that name, though some writers have confused her with the fourth. Freeman clearly knew more about Darwin than most of Darwin's biographers. In his Darwin Pedigrees (1984), he reprinted H. Farnham Burke's scarce Pedigree of the Family of Darwin (1888) and added a wealth of information about Darwin's numerous relations by blood and marriage down to the present day.'

In 1986, Freeman published Additions and Corrections to his Darwin bibliography, a booklet containing about 300 items, circulated principally to those people who had helped him to collect information. Two entries refer to different editions of a minor work omitted from the bibliography, 'which l had in xerox but forgot'. This was typical of Freeman's candour, which accompanied a genuine modesty about his great erudition.

\section{W.A. SMEATON}

'Privately published by R.B. Freeman. Now available from Dr Mary Whitear, Department of Zoology, University College London, Gower Street, London WC1E 6BT, U.K. Price $£ 12.50$. 